\title{
A review of nutritional value and putative health-effects of quince (Cydonia oblonga Mill.) fruit
}

\author{
Hegedüs, A. ${ }^{1}$, Papp, N. $^{2}$ \& Stefanovits-Bányai, É. ${ }^{2}$ \\ ${ }^{1}$ Corvinus University of Budapest, Faculty of Horticultural Science, Department of Genetics and Plant Breeding, \\ 1118 Budapest, Villányi út 29., Hungary; E-mail: hegedus.attila@uni-corvinus.hu \\ ${ }^{2}$ Corvinus University of Budapest, Faculty of Food Science, Department of Applied Chemistry, \\ 1118 Budapest, Villányi út 29., Hungary
}

\begin{abstract}
Summary: Quince (Cydonia oblonga Mill.) has been long regarded to be a health-promoting fruit. Although it is mainly consumed in processed form, its relatively heat-stable polyphenolics were confirmed to be responsible for most of the beneficial effects. This review aims to show basic nutritional information on quince fruit such as carbohydrate, fibre, pectin and mineral element contents. In addition, vitamin and polyphenolic contents and composition as well as the physiological effects of quince consumption were also surveyed. Information on presumable protective effects against several diseases including inflammation, atopic dermatitis, ulcers and cancer is summarized. Potential antibacterial effects of quince polyphenolics were also considered. Polyphenolics are supposed to be responsible for the major part of beneficial health-effects, and phenolic compounds predominantly accumulate in peel. There exists a considerable extent of genetic variation in phytochemical composition among cultivars, which might be exploited in designing future breeding programs for quince improvement and opening new ways for health-related uses.
\end{abstract}

Key words: Cydonia oblonga, health, nutrients, polyphenolics, quince

\section{Introduction}

Quince might be used in a several ways, many processed forms of this fruit gained worldwide popularity. Fruits can be processed into juices, jams and spirits. Persian physicians advised patients suffering from chronic recurrent headache to eat a quince before breakfast due to its apparent prophylactic effects (Gorji, 2003). Others suppose quince jam is beneficent in gastrointestinal disorders. In many countries throughout Europe, Asia and Africa, quince is used as a component in traditional dishes.

\section{Nutritional composition}

The nutritional composition of quince is compared with apple, a close relative of this fruit crop but consumed in great quantities. All data are expressed for $100 \mathrm{~g}$ fresh weight of whole fruits according to Bíró and Lindner (1999). Energy, protein, acid, carbohydrate, ash and fibre contents in quinces are higher than those in apples, while quince fruit contains less water (Table 1).

The contents of pectins in fruits ranged between 1.75 and $3.51 \mathrm{~g} / 100 \mathrm{~g} \mathrm{FW}$, and cultivar 'Hruškovita' accumulated pectins in greatest amount ( $R o p$ et al., 2011). The quince pectin had a high galacturonic content (78\%), and a degree
Table 1. Main nutritional composition of quince and apple ('Jonathan') fruits in $100 \mathrm{~g}$ fresh weight (Bíró and Lindner, 1999)

\begin{tabular}{|l|c|c|c|c|c|c|c|}
\hline & $\begin{array}{c}\text { Energy } \\
(\mathrm{kJ})\end{array}$ & $\begin{array}{c}\text { Protein } \\
(\mathrm{g})\end{array}$ & $\begin{array}{c}\text { Acid } \\
(\mathrm{g})\end{array}$ & $\begin{array}{c}\text { Carbo- } \\
\text { hydrate } \\
(\mathrm{g})\end{array}$ & $\begin{array}{c}\text { Water } \\
(\mathrm{g})\end{array}$ & $\begin{array}{c}\text { Ash } \\
(\mathrm{g})\end{array}$ & $\begin{array}{c}\text { Fibre } \\
(\mathrm{g})\end{array}$ \\
\hline Apple & 130 & 0.4 & 0.4 & 7.0 & 90.5 & 0.4 & 1.3 \\
\hline Quince & 176 & 0.6 & 0.9 & 9.1 & 86.9 & 0.6 & 1.9 \\
\hline
\end{tabular}

of methoxylation of about $60 \%$ corresponding to a mediumhigh methoxyl pectin (Forni et al., 1994).

Vitamin C content of quince is nearly two-times higher than in apple (Bíró and Lindner, 1999) (Table 2), while other authors reported nearly identical quantities of ascorbic acid in quinces and apples (13 and $12 \mathrm{mg} / 100 \mathrm{~g}$, respectively) (Souci et al., 2002). According to Bíró and Lindner (1999) apple contains more from most of the vitamins, while Souci et al. (2002) determined nearly identical amounts of vitamins in both fruit crops.

For Czech cultivars, the vitamin $\mathrm{C}$ contents in quince ranged from 50 to $80 \mathrm{mg} / 100 \mathrm{~g}$ intact fruit (flesh and peel together). Fruits of the cultivar 'Muškatová' contained the highest amount, $79.31 \pm 2.01 \mathrm{~g} / 100 \mathrm{~g} \mathrm{FW}$ of acorbic acid (Rop et al., 2011). This value is definitely higher than those specified in Table 2 or compared with the USDA reference value of $15 \mathrm{mg}$ (USDA, 2012), which confirms that quince 
Table 2. The vitamin contents in $100 \mathrm{~g}$ fresh quince and apple ('Jonathan') fruit according to Bíró and Lindner (1999) and Souci et al. (2002)

\begin{tabular}{|l|c|c|c|c|c|c|}
\hline \multirow{2}{*}{} & \multirow{2}{*}{ Vitamin } & \multirow{2}{*}{ Dimension } & \multicolumn{2}{l|}{ Bíró and Lindner (1999) } & \multicolumn{2}{c|}{ Souci et al. (2002) } \\
\cline { 4 - 7 } & & & Apple & Quince & Apple & Quince \\
\hline Retinol & $\mathrm{A}$ & $\mu \mathrm{g}$ & 0.0 & 0.0 & 5.7 & 5.5 \\
\hline Carotene & & $\mathrm{mg}$ & 0.05 & $\mathrm{nd}$ & 0.04 & 0.03 \\
\hline Calciferol & $\mathrm{D}$ & $\mu \mathrm{g}$ & 0 & 0 & $\mathrm{nd}$ & $\mathrm{nd}$ \\
\hline Tocopherol & $\mathrm{E}$ & $\mathrm{mg}$ & 0.60 & $\mathrm{nd}$ & 0.49 & $\mathrm{nd}$ \\
\hline Thiamine & $\mathrm{B}_{1}$ & $\mu \mathrm{g}$ & 50 & 25 & 35 & 30 \\
\hline Riboflavin & $\mathrm{B}_{2}$ & $\mu \mathrm{g}$ & 50 & 25 & 32 & 30 \\
\hline Niacin & $\mathrm{B}_{3}$ & $\mathrm{mg}$ & 0.5 & 0.2 & 0.3 & 0.2 \\
\hline Pantothenic acid & $\mathrm{B}_{5}$ & $\mathrm{mg}$ & 0.09 & $\mathrm{nd}$ & 0.10 & $\mathrm{nd}$ \\
\hline Pyridoxine & $\mathrm{B}_{6}$ & $\mathrm{mg}$ & 0.070 & $\mathrm{nd}$ & 0.103 & $\mathrm{nd}$ \\
\hline Biotin & $\mathrm{B}_{7}$ & $\mu \mathrm{g}$ & 1.0 & $\mathrm{nd}$ & 4.5 & $\mathrm{nd}$ \\
\hline Folic acid & $\mathrm{B}_{9}$ & $\mu \mathrm{g}$ & 6.0 & $\mathrm{nd}$ & 7.5 & $\mathrm{nd}$ \\
\hline Cyanocobalamin & $\mathrm{B}_{12}$ & $\mu \mathrm{g}$ & 0.0 & 0.0 & $\mathrm{nd}$ & $\mathrm{nd}$ \\
\hline Ascorbic acid & $\mathrm{C}_{1}$ & $\mathrm{mg}$ & 5 & 10 & 12 & 13 \\
\hline
\end{tabular}

nd: non-detected

cultivars are characterized by a great genetic variability. It was also confirmed by determining fruit antioxidant capacity and total polyphenolic contents in 12 commercial cultivars (Papp et al., in press).

Quince is a richer source of mineral elements compared to apple. The summarized quantity of the measured mineral elements is almost two-times higher in quince than apples (Table 3).

Table 3. Mineral element contents in $100 \mathrm{~g}$ quince and apple ('Jonathan') fruits (Bíró and Lindner, 1999)

\begin{tabular}{|l|c|c|c|}
\hline & Dimension & Apple & Quince \\
\hline $\mathrm{Na}$ & $\mathrm{mg}$ & 2.0 & 9.2 \\
\hline $\mathrm{K}$ & $\mathrm{mg}$ & 112 & 189 \\
\hline $\mathrm{Ca}$ & $\mathrm{mg}$ & 5.5 & 66.0 \\
\hline $\mathrm{Mg}$ & $\mathrm{mg}$ & 6 & 10 \\
\hline $\mathrm{Fe}$ & $\mathrm{mg}$ & 0.3 & 1.1 \\
\hline $\mathrm{P}$ & $\mathrm{mg}$ & 8 & 25 \\
\hline $\mathrm{Cu}$ & $\mathrm{mg}$ & 0.028 & 0.006 \\
\hline $\mathrm{Zn}$ & $\mathrm{mg}$ & 0.046 & 0.013 \\
\hline $\mathrm{Mn}$ & $\mathrm{mg}$ & 0.037 & 0.002 \\
\hline $\mathrm{Co}$ & $\mathrm{mg}$ & 0.001 & $\mathrm{nd}$ \\
\hline $\mathrm{Cr}$ & $\mathrm{mg}$ & 0.002 & $\mathrm{nd}$ \\
\hline $\mathrm{Ni}$ & $\mathrm{mg}$ & 0.011 & $\mathrm{nd}$ \\
\hline Total quantity & $\mathrm{mg}$ & 133.9 & 300.3 \\
\hline
\end{tabular}

The unique fragrance of quince fruit is attributable to the specific composition of its essential oil (Schreyen et al., 1979; Tsuneya et al., 1983) in which the characteristic compounds were thought to be monoterpenic lactones and oxides (Tsuneya et al., 1983). In the early nineties, Lutz et al. (1991) indicated the presence of monoterpenic glucosides in quince, which were supposed to be the putative precursors of the lactones and oxides.

\section{Polyphenolic composition of quince fruit}

Qualitative and quantitative analyses of phenolic compounds were carried out on quince fruit samples from seven different geographical origins in Portugal (Silva et al., 2002). Both fruit flesh and peel were analyzed by reversed-phase high performance liquid chromatography (HPLC) coupled with diode array detector or mass spectrometry. Differences were noted between the phenolic profiles of flesh and peel in all studied cases. The flesh contained mainly caffeoylquinic acids (3-, 4-, and 5-O-caffeoylquinic acids and 3,5-dicaffeoylquinic acid) and rutin (quercetin 3-O-rutinoside). The peel presented the same caffeoylquinic acids and several flavonol glycosides: quercetin 3-galactoside, kaempferol 3-glucoside, kaempferol 3 -rutinoside, and several unidentified compounds. The highest content of phenolics was found in peels.

In Tunisian quinces, total phenolic contents of the flesh and peel parts ranged from 37 to 47 and 105 to $157 \mathrm{mg} / 100$ $\mathrm{g}$ of fresh weight, respectively (Fattouch et al., 2007). Chlorogenic acid (5-O-caffeoylquinic acid) was the most abundant phenolic compound in flesh (37\%), whereas rutin was the main one in peel $(36 \%)$.

A total of 26 polyphenolic compounds found in quince tissues were identified (Wojdylo et al., 2013): 9 flavan-3-ols including (-)-epicatechin, procyanidin $\mathrm{B} 2,3$ procyanidin dimers and trimers, and 1 tetramer; 8 hydroxycinnamates (derivatives of caffeoylquinic and coumaroylquinic acid) and 9 kaempferol and quercetin derivatives. The content of total polyphenols ranged between 1709 and $3437 \mathrm{mg} / 100 \mathrm{~g}$ dry weight ('Leskovač'). Flavan-3-ols, which form the major class of quince polyphenols, represented approx. the 78 and $94 \%$ of the total polyphenolic content.

\section{Putative health-effects of quince consumption}

Quince was reported to have antiulcerative effects (Hamauzu et al., 2006). However, the strongest antiulcerative effect was declared for Chinese quince (Pseudocydonia sinensis C. K. Schneid.) on ethanol-induced gastric ulcers in rats. Pre-administration of Chinese quince and quince phenolics suppressed the occurrence of gastric lesions in rats, whereas apple phenolics seemed to promote ulceration. The antioxidative property of rat blood increased in all rats fed by quince phenolics. Ferulic acid and isoferulic acid were detected as major metabolites in rats consuming 
apple phenolics, quince phenolics, and 5-caffeoylquinic acid standard. (-)-Epicatechin and its 3'-O-methyl ether were detected in rats administered apple phenolics and (-)-epicatechin standard. The results showed that Chinese quince and quince phenolics might have health benefits by acting both in blood vessels and on the gastrointestinal tract.

Chronic inflammation is a hallmark of several diseases including diabetic complications, rheumatoid arthritis, inflammatory bowel disease, atherosclerosis and cancer. Essafi-Benkhadir et al. (2012) reported the anti-inflammatory effect of a polyphenolic extract from Tunisian quince. Lipopolysaccharide (LPS) treatment of human THP-1derived macrophages induced the secretion of high levels of the pro-inflammatory cytokine TNF- and IL-8, which was inhibited by quince peel polyphenolic extract in a dosedependent manner. Quince polyphenols also enhanced the level of the anti-inflammatory cytokine IL-10 secreted by LPS-treated macrophages. Quince polyphenols inhibited the LPS-mediated activation of three major cellular proinflammatory effectors (nuclear factor-kappa B, p38MAPK and $\mathrm{Akt}$ ). These data indicate that quince peel polyphenolic extract induces a potent anti-inflammatory effect and that a quince-rich diet may help to prevent and improve the treatment of inflammation-associated diseases.

Shinomiya et al. (2009) examined the effect of a crude hot-water extract (HW) of quince fruit on type I allergy in vivo and in vitro. The oral administration of the quince $\mathrm{HW}$ added diet to $\mathrm{NC} / \mathrm{Nga}$ mice (NC/Nga mice are known to exhibit spontaneous development of dermatitis) for 63 days showed a significant decrease in the development of atopic dermatitis-like skin lesions under conventional conditions. The concentration of IgE in the serum collected from mice fed with quince HW was lowered in a dose-dependent manner. Moreover, quince HW inhibited the release of betahexosaminidase from rat basophilic leukaemia cells after a 24-hour treatment. The quince HW fraction of less than 3 $\mathrm{kDa}$ reduced the mRNA expression of the high-affinity $\operatorname{IgE}$ receptor (Fc RI) subunit. These results suggest that quince HW had an inhibitory effect on type I allergy by suppressing $\mathrm{IgE}$ production and IgE-mediated degranulation.

Alesiani et al. (2010) identified several compounds with antiproliferative effects from quince peels although Carvalho et al. (2010) could not show inhibitory effects of quince fruit flesh and peel on human kidney and colon cancer cells. However, the extracts from leaf showed concentration-dependent growth inhibitory activity toward human colon cancer cells, while no effect was observed in renal adenocarcinoma. Seed extracts exhibited no effect on colon cancer cell growth, whereas strong antiproliferative efficiency was observed against renal cancer cells for the highest concentration tested $(500 \mu \mathrm{g} / \mathrm{mL})$.

The antimicrobial activity of quince extracts against different microorganism strains was investigated by Fattouch et al. (2007). Quince peel extract was the most active for inhibiting bacterial growth. It seems that chlorogenic acid acts in synergism with other components of the extracts to exhibit total antimicrobial activities. Thirty-four polyphenols were detected by Karar et al. (2013), nine of which were not reported previously in quince. The crude extract of quince fruit polyphenols showed antibacterial activity against the Gram-negative bacterium Escherichia coli. Five polyphenols, 5-O-caffeoylquinic acid, quinic acid, quinic acid derivative, proanthocyanin $\mathrm{B} 1$ and methyl 5- $O$-caffeoylquinate were isolated and tested for their antibacterial activity. Quinic acid and a quinic acid derivative showed strong inhibition against E. coli.

An interesting study was published on the comparison of the phenolic profile and antioxidant potential of quince leaf and green tea (Camellia sinensis) (Costa et al., 2009). Quince leaf exhibited a significantly higher reducing power than green tea (mean value of $227.8 \pm 34.9$ and $112.5 \pm 1.5 \mathrm{~g} / \mathrm{kg}$ dry leaf, respectively). Quince leaf extracts showed similar 2,2'-diphenyl-1-picrylhydrazyl (DPPH) radical-scavenging activities but significantly lower than that presented by green tea extract. Under the oxidative action of 2,2'-azobis(2amidinopropane) dihydrochloride, quince leaf methanolic extract significantly protected the erythrocyte membrane from hemolysis in a similar manner to that found for green tea. These results point to the fact that quince leaf may be applied as a preventive or therapeutic agent in diseases associated with free radical damage.

In conclusion, the review of the papers focused on quince phytochemical composition indicates a considerable extent of genetic variations among cultivars and also allowed to identify perspective therapeutic targets. Since polyphenolics are supposed to be responsible for the major part of beneficial health-effects, this information might be exploited in designing future breeding programs for quince improvement and opening new ways for health-related uses including the development of quince-based functional foods.

\section{Acknowledgements}

This work was financed by the OTKA K84290 grant. Attila Hegedüs is grateful for receiving a János Bolyai Scholarship, Hungarian Academy of Sciences.

\section{References}

Alesiani, D., Canini, A., D’Abrosca, B., DellaGreca, M., Fiorentino, A., Mastellone, C., Monaco, P. \& Pacifico, S. (2010): Antioxidant and antiproliferative activities of phytochemicals from quince (Cydonia vulgaris) peels. Food Chem., 118: 199-207.

Bíró Gy. \& Lindner K. (1999): Tápanyagtáblázat. Medicina, Budapest

Carvalho, M., Silva, B.M., Silva, R., Valentao, P., Andrade, P.B. \& Bastos, M.L. (2010): First report on Cydonia oblonga Miller anticancer potential: differential antiproliferative effect against human kidney and colon cancer cells. J. Agr. Food Chem., 58: 3366-3370.

Costa, R.M., Magalhăes, A.S., Pereira, J.A., Andrade, P.B., Valentăo, P., Carvalho, M. \& Silva, B.M. (2009): Evaluation 
of free radical-scavenging and antihemolytic activities of quince (Cydonia oblonga) leaf: A comparative study with green tea (Camellia sinensis). Food Chem. Toxicol., 47: 860-865.

Essafi-Benkhadir, K., Refai, A., Riahi, I., Fattouch, S., Karoui, H. \& Essafi, M. (2012): Quince (Cydonia oblonga Miller) peel polyphenols modulate LPS-induced inflammation in human THP-1-derived macrophages through NF- $\mathrm{B}$, p38MAPK and Akt inhibition. Biochem. Biophys. Res. Com., 418: 180-185.

Fattouch, S., Caboni, P., Coroneo, V., Tuberoso, C.I.G., Angioni, A., Dessi, S., Marzouki, N. \& Cabras, P. (2007): Antimicrobial activity of Tunisian quince (Cydonia oblonga Miller) pulp and peel polyphenolic extracts. J. Agr. Food Chem., 55: 963-969.

Forni, E., Penci, M., Polesello, A. (1994): A preliminary characterization of some pectins from quince fruit (Cydonia oblonga Mill.) and prickly pear (Opuntia ficus indica) peel. Carbohyd. Polym., 23: 231-234.

Gorji, A. (2003): Pharmacological treatment of headache using traditional Persian medicine. Trends Pharmacol. Sci., 24: 331-334.

Hamauzu, Y., Inno, T., Kume, C., Irie, M. \& Hiramatsu, K. (2006): Antioxidant and antiulcerative properties of phenolics from Chinese quince, quince, and apple fruits. J. Agr. Food Chem., 54: 765-772.

Karar, M.G.E., Pletzer, D., Jaiswal, R., Weingart, H. \& Kuhnert, N. (2013): Identification, characterization, isolation and activity against Escherichia coli of quince (Cydonia oblonga) fruit polyphenols. Food Res. Int. (in press).

Lutz, A., Winterhalter, P. \& Schreier, P. (1991): Isolation of a glucosidic precursor of isomeric marmelo oxides from quince fruit. Tetrahedron Lett., 32: 5943-5944.
Papp, N., Szabó, T., Szabó, Z., Nyéki, J., Stefanovits-Bányai, É. \& Hegedús, A. (2013): Antioxidant capacity and total polyphenolic content in quince (Cydonia oblonga Mill.) fruit. Int. J. Hort. Sci. (in press).

Rop, O., Balik, J., Řezniček, V., Jurikova, T., Škardova, P., Salaš, P., Sochor, J., Mlček, J. \& Kramařova, D. (2011): Chemical characteristics of fruits of some selected quince (Cydonia oblonga Mill.) cultivars. Czech J. Food Sci., 29: 65-73.

Schreyen, L., Dirinck, P., Sandra, P. \& Schamp, N. (1979): Flavor analysis of quince. J. Agr. Food Chem., 27: 872-876.

Shinomiya, F., Hamauzu, Y. \& Kawahara, T. (2009): Antiallergic effect of a hot-water extract of quince (Cydonia oblonga). Biosci. Biotech. Bioch., 73: 1773-1778.

Silva, B.M., Andrade, P.B., Ferreres, F., Domingues, A.L., Seabra, R.M. \& Ferreira, M.A. (2002): Phenolic profile of quince fruit (Cydonia oblonga Miller) (pulp and peel). J. Agr. Food Chem., 50: 4615-4618.

Souci, S.W., Fachmann, W. \& Kraut, H. (2008): Food composition and nutrition tables. Taylor and Francis, London.

Tsuneya, T., Ishihara, M., Shiota, H. \& Shiga, M. (1983): Volatile components of quince fruit (Cydonia oblonga Mill.). Agr. Biol. Chem., 47: 2495-2502.

U.S. Department of Agriculture, Agricultural Research Service (2012): USDA National Nutrient Database for Standard Reference, Release 25. http://www.ars.usda.gov/ba/bhnrc/ndl

Wojdylo, A., Oszmianski, J., Teleszko, M., Sokol-Letowska, A. (2013): Composition and quantification of major polyphenolic compounds, antioxidant activity and colour properties of quince and mixed quince jams. Int. J. Food Sci. Nutr. 64: 749-756. 